\title{
A Note on the Legal Theory of Constructive Deceit
}

\author{
Dale Buckmaster \\ and \\ Melinda Kwart \\ Department of Business Administration \\ University of Delaware
}

This article is about one aspect of stockholder rights when there is a corporate merger or takeover. Corporate mergers and takeovers have become common events in recent years. Few corporations are safe from a takeover bid. The financial benefits to stockholders of target companies are likely to vary considerably among these stockholders, particularly when the target company is a relatively small, closely held organization. As a result, the facts related to the merger or takeover transactions are frequently misrepresented or in adequately disclosed. There are state and federal laws to protect the rights of stockholders who might be financially injured from being misled about a merger or takeover transaction. Generally federal jurisdiction is considered more advantageous to the injured stockholders than pursuing a suit in the state courts. Thus, it is worth while for directors and stockholders to be aware of the possible determinants of which the court has jurisdiction. In this article we discuss both the availability of a federal forum under current legal theory, as well as the advantages of electing this option.

Section 10 and Rule 10b-5 of the Securities Exchange Act of 1934 (8) may provide injured minority stockholders a course of action in a merger or takeover when there is no remedy in the state courts. The theory of constructive deceit has been used as one interpretation of Rule 10b-5 that greatly expands the availability of a federal suit. The objective of this article is to provide a general description of this theory and its utility in determining the jurisdictional location of a suit.

\section{Rule 10b-5 and the Theory of Constructive Deceit}

Rule $10 \mathrm{~b}-5$ of the Securities Act of 1934 reads:

It shall be unlawful for any person, directly or indirectly, by the use of any means or instrumentality of interstate commerce or of the mails or of any facility of any national securities exchange (a) to employ any device, scheme, or artifice to defraud, (b) to make any untrue statement of a material fact or to omit to state a material fact necessary in order to make the statements made, in the light of the circumstances under which they were made, not misleading, 
or (c) to engage in any act, practice, or course of business which operates or would operate as a fraud or deceit upon any person, in connection with the purchase or sale of any security.

The question of when a rule $10 \mathrm{~b}-5$ suit may be properly brought before the federal courts is of some importance and the determinants of when this might occur have changed over the years. At present, the legal theory of constructive deceit allows an injured stockholder a chance to bring a suit under Rule 10b-5 in cases in which the share holder formerly may have been thwarted from instituting such a federal claim.

The theory of constructive deceit suggests that when a corporation has purchased or sold securities under the control of a group of its directors who are engaging in an undisclosed course of self-dealing, then the corporation has been deceived in its function as representative of the minority interests. Deceit, a necessary element to a rule $10 \mathrm{~b}-5$ action, is difficult to establish with a corporate victim since a corporation is normally imputed with the knowledge of its agents. However, under the theory of constructive deceit, which is supported by agency principles, there is a different result if a sufficient number of interested directors are involved since knowledge acquired in selfdealing is not imputed to the corporation.

However, in order to prevail in a rule $10 \mathrm{~b}-5$ case, it is necessary to prove that the omission or misrepresentation is sufficiently material to have kept the stockholder from redressing what would have been a recognized wrong in state court. In GOLDBERG v. MERIDOR (2), for instance, a successful rule 10b5 action was brought on behalf of the corporation challenging the issuance of shares for inadequate consideration under the theory that the corporation was prompted to make this issuance by its controlling shareholder who personally benefited from the arrangement. The unfairness of the exchange was covered up with the use of misleading press releases. Had the shareholders known of the inadequacy, they could have pursued an injunction remedy under state law. On this basis, the court concluded that the materiality factor was met, and therefore a rule $10 \mathrm{~b}-5$ suit was made out.

Some federal circuits have not fully accepted the availability of a federal securities suit when a director or officer has concealed or failed to disclose some act of negligence, even when it is actionable under state law. The case of BIESENBACH v. GUENTHER (1), for example, involved a claim that the corporation's directors failed to disclose the true purpose behind a transaction that they misleadingly reported was in the shareholders' best interests. In response, the Third Circuit came to the somewhat anomalous conclusion that " $[\mathrm{t}]$ he unclean heart of a director is not actionable, whether or not it is 'disclosed', unless the impurities are translated into actionable deeds or omissions both objective and external." [p.402] Many federal circuits have acknowledged that such a federal claim exists but limit its accessibility to those occasions where a shareholder can first prove that he or she would have succeeded or would have a reasonable probability of succeeding in obtaining 
a remedy in a state forum. [See, for example, $(3),(4)$, and (8).]

\section{Constructive Deceit and Santa Fe Industries, Inc. v. Green}

Judge Friendly of the Second Circuit formalized the theory of constructive deception in which a corporation can be deceived through its stockholders. The rule states "there is deception of the corporation (in effect, of its minority shareholders) when the corporation is influenced by its controlling shareholders to engage in a transaction adverse to the corporation's interests (in effect, the minority shareholders' interests) and there is nondisclosure or misleading disclosure as to the material facts of the transaction." (2) The theory initially failed to develop because it was inconsistent with the theory of "new fraud", an alternate and more popular interpretation of Rule 10b-5. Under the "new fraud" theory, no showing of deceit is necessary to predicate a rule $10 \mathrm{~b}-5$ claim despite the apparent $10 \mathrm{~b}-5$ requirement for such. This theory merely requires a showing of unfairness or a general breach of fiduciary duty rather than deception. But the Supreme Court effectively dismissed the theory of "new fraud" in the SANTA FE INDUSTRIES (5) case. This opened the way for the acceptance and refinement of the theory of constructive deceit.

In footnote 14 of the SANTA FE INDUSTRIES case, the Supreme Court recognized that a federal rule $10 \mathrm{~b}-5$ cause of action can be premised on any breach of fiduciary duty that might have led to a state remedy had it been disclosed. (1, p.474) This failure to disclose then constitutes a material omission which deceives the stockholder. Unfortunately, this suit was unavailable to many stockholders because the proposed corporate action which the shareholder sought to contest was commonly effectuated through the corporation's purchase or sale of securities. In this way, the stockholder could not establish a necessary prerequisite to the institution of a rule $10 \mathrm{~b}-5$ suit, his personal purchase or sale of securities. At this stage, the theory of constructive deceit became most useful, allowing the worsted shareholder to institute a derivative rule $10 \mathrm{~b}-5$ action on behalf of the corporation, which constitutes the investor in the disputed transaction.

\section{Implications for Directors and Stockholders}

The theory of constructive deceit is the common law rule that is currently used to determine whether cases involving minority stockholders opposing a merger will be under the jurisdiction of state courts or federal courts. Where the cases are heard may be of considerable consequence. Plaintiffs generally prefer federal to state forums because of the availability of nationwide service of process, liberal class action rules, jury trials and relief from state security-for-expenses requirements. Furthermore, remedies for the minority stockholders in state courts are normally limited to the appraisal remedy. That is, the minority stockholders may be reimbursed for the appraised fair market value of their stock. In SMITH v. VAN GORKOM, for example, the complaining class of shareholders was accorded the fair value of their holdings and denied the requested rescission of a cash-out merger, despite the 
court's determination that the board had acted in a grossly negligent manner by failing to disclose all material facts before soliciting shareholder approval. $(6, p .890)$ On the other hand, it is possible that the injured minority stockholders might obtain some kind of equitable relief in the federal courts, such as an injunction blocking the merger or the recovery of the shares by the issuer. Alternatively, the investor may obtain an award of monetary damages not limited to the worth of the shares alone but determined by the losses sustained by the investor.

\section{References}

1. Biesenbach v. Guenther, 588 F.2d 400 (3d Cir. 1978).

2. Goldberg v. Meridor, 567 F.2d 209 (2d Cir. 1977) cert. denied, 434 U.S. 1069 (1978).

3. Healy v. Catalyst Recovery, Inc., 616 F.2d 641 (3d Cir. 1980).

4. Kidwell ex rel Penfold v. Meikle, 597 F.2d 1273 (9th Cir. 1979).

5. Santa Fe Industries, Inc. v. Green, 430 U.S. 462 (1977).

6. Smith v. VanGorkom, 488 A.2d 858 (Del. 1985).

7. Wright v. Heizer Corp., 560 F.2d 236 (7th Cir. 1977), cert. denied, 434 U.S. 1066 (1978).

8. 17 CFR Section 240. 10b-5 (1976). 